\title{
Hepcidin Serum Levels and Resistance to Recombinant Human Erythropoietin Therapy in Haemodialysis Patients
}

\author{
Elísio Costa $^{a, b}$ Dorine W. Swinkels ${ }^{i, j} \quad$ Coby M. Laarakkers ${ }^{i}$ \\ Petronila Rocha-Pereira ${ }^{e}$ Susana Rochab c ${ }^{b l a ́ v i o ~ R e i s ~}{ }^{f}$ Frederico Teixeira ${ }^{f}$ \\ Vasco Mirandag Maria do Sameiro Fariag ${ }^{9}$ Alfredo Loureiro $^{\text {h }}$ \\ Alexandre Quintanilhab, ${ }^{b}$ Luís Belo ${ }^{b, c}$ Alice Santos-Silvab,

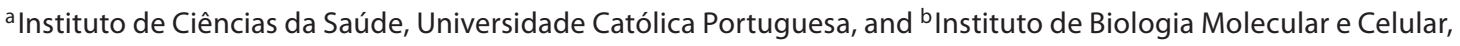 \\ 'Faculdade de Farmácia, Serviço de Bioquímica and 'Instituto de Ciências Biomédicas Abel Salazar, \\ Universidade do Porto, Porto, ${ }^{e}$ Centro de Investigação Ciências da Saúde, Universidade da Beira Interior, Covilhã, \\ f Instituto de Farmacologia e Terapêutica Experimental, IBILI, Faculdade de Medicina, Universidade de Coimbra, \\ Coimbra, ${ }^{9}$ FMC, Dinefro - Diálises e Nefrologia, SA, Porto, and h Uninefro - Sociedade Prestadora de Cuidados \\ Médicos e de Diálise, SA, Santo Tirso, Portugal; ' Hepcidinanalysis.com and 'Department of Laboratory Medicine (441), \\ Radboud University Nijmegen Medical Center, Nijmegen, The Netherlands
}

Recently, a complex regulatory network that governs iron traffic has emerged, and points to hepcidin as a major evolutionary conserved regulator of iron distribution $[1,2]$. This small hormone produced by the mammalian liver has been proposed as a central mediator of dietary iron absorption. Hepcidin was found to be associated with decreases in both iron uptake from the small intestine and release of iron from macrophages, as well as decreased placental iron transport $[1,2]$. The synthesis of hepcidin is stimulated by anaemia/hypoxia, inflammation and iron overload. It is synthesized as a preprohepcidin of 84 amino acids. The signal peptide is cleaved leading to the 60 -amino acid prohepcidin, which is further processed giving rise to the 25 -amino acid hepcidin $[3,4]$.

Hepcidin synthesis is regulated by inflammation, a common finding in haemodialysis (HD) patients, being enhanced in those that do not respond to recombinant human erythropoietin (rhEPO) therapy. On the other hand, it will be demonstrated that erythropoietin down- regulates liver hepcidin expression, acting, therefore, as a hepcidin-inhibitory hormone $[1,5]$. Anaemia/hypoxia seems to be the third factor that regulates hepcidin expression. In fact, anaemia is associated with a decrease in hepcidin expression, resulting in an increase in intestinal iron absorption and iron release by the macrophages in order to augment iron availability for erythropoiesis [6].

We sought, therefore, to study the relationship between hepcidin serum levels and haematological data, iron status, inflammatory markers and rhEPO doses in HD patients.

We selected $33 \mathrm{HD}$ patients (15 males, 18 females; mean age $59.5 \pm 17.6$ years) under rhEPO treatment for a median time period of 36 months. All patients used the high-flux polysulfone FX-class dialyzers of Fresenius. The HD patients included 16 responders and 17 non-responders to rhEPO therapy. Classification of HD patients, as responders or non-responders, was performed in accordance with the European Best Practice Guidelines [5]. The rhEPO maintenance dose for responder pa-

\section{KARGER}

Fax +41613061234 E-Mail karger@karger.ch www.karger.com (c) 2009 S. Karger AG, Basel

0001-5792/09/1224-0226\$26.00/0

Accessible online at:

www.karger.com/aha
Elísio Costa

Instituto de Ciências da Saúde, Universidade Católica Portuguesa

Rua Dr. António Bernardino de Almeida, PT-4200-072 Porto (Portugal)

Tel. +351 22558 0001, Fax +351 225090351

E-Mail elisio_costa@ hotmail.com or ecosta@ics.porto.ucp.pt 
tients was $95.9 \pm 68.5 \mathrm{U} / \mathrm{kg} /$ week and for non-responders it was $512.6 \pm 215.0 \mathrm{U} / \mathrm{kg} /$ week. The 2 groups of patients were matched for age, gender, weight, body mass index, mean time on $\mathrm{HD}$, urea reduction ratio, urea $\mathrm{KtV}$ and parathyroid hormone serum levels. Patients with autoimmune disease, malignancy, haematological disorders, acute or chronic infection and blood transfusion within the last 4 months were excluded from the study. Healthy volunteers $(\mathrm{n}=17)$ with normal haematological and biochemical values and without any history of renal or inflammatory disease were used as normal controls. They were matched as far as possible for age and gender with HD patients.

In all patients and controls, red blood cell (RBC) count, haematocrit, haemoglobin $(\mathrm{Hb})$ concentration, haematological indices and red cell distribution width (RDW) were measured by using an automatic blood cell counter (Sysmex K1000; Sysmex, Hamburg, Germany). Serum iron concentration was determined using a colorimetric method (iron; Randox Laboratories Ltd., Crumlin, UK), whereas serum ferritin and serum transferrin (Randox Laboratories) were measured by immunoturbidimetry. Enzyme-linked immunosorbent assays were used for measurement of plasma soluble transferrin receptor (sTfR; human sTfR immunoassay, R\&D Systems, Minneapolis, Minn., USA) and serum prohepcidin concentrations (Hepcidin Prohormone ELISA; IBL, Hamburg, Germany). Serum C-reactive protein (CRP) was determined by nephelometry ( $\mathrm{N}$ high sensitivity CRP; Dade Behring, Germany), and serum IL- 6 levels were quantified using the $\mathrm{BD}^{\mathrm{TM}}$ Cytometric Bead Array Human Th1/ Th2 Cytokine Kit II (BD Biosciences, San Diego, Calif., USA), and analyzed using the $\mathrm{BD}^{\mathrm{TM}}$ CBA Software.

Serum hepcidin measurements were performed by a combination of weak cation exchange chromatography and time-of-flight mass spectrometry. An internal standard (synthetic hepcidin-24; Peptide International Inc., Louisville, Ky., USA) was used for quantification. Peptide spectra were generated on a Microflex LT matrix-enhanced laser desorption/ionization time-of-flight mass spectrometry platform (Bruker Daltonics, Germany). Serum hepcidin-25 concentrations were expressed as $\mathrm{nmol} / \mathrm{l}$. The lower limit of detection of this method was $0.5 \mathrm{nmol} / \mathrm{l}$; average coefficients of variation were $2.7 \%$ (intrarun) and 6.5\% (interrun) [7, 8].

For statistical analysis, we used the Statistical Package for Social Sciences, version 14.0. Kolmogorov-Smirnov statistics were used to evaluate sample normality distribution. Comparisons between groups were performed using Kruskal-Wallis test and Mann-Whitney U (data with a non-Gaussian distribution) or one-way ANOVA supplemented with Tukey's HSD post hoc test (data with a Gaussian distribution). Spearman's rank correlation coefficient was used to evaluate relationships between sets of data. Multiple regression analysis using the stepwise method was used to determine independent factors $(\mathrm{Hb}$ concentration, RBC count, haematocrit, serum levels of transferrin, ferritin, s-TfR, CRP and interleukin 6, and weekly rhEPO dose) affecting prohepcidin and hepcidin serum levels. Significance was accepted at $p<0.05$.

Compared to controls, HD patients presented with significantly lower RBC count $(3.6 \pm 0.6$ vs. $4.7 \pm 0.5 \times$ $\left.10^{12} / \mathrm{l}, \mathrm{p}<0.05\right)$, Hb concentration (11.0 \pm 1.7 vs. $13.8 \pm$ $1.1 \mathrm{~g} / \mathrm{dl}, \mathrm{p}<0.05)$, haematocrit $(34.0 \pm 5.0$ vs. $42.6 \pm$ $3.8 \%, \mathrm{p}<0.05)$ and transferrin levels $(181.8 \pm 57.5$ vs. $247.6 \pm 58.4 \mathrm{mg} / \mathrm{dl}, \mathrm{p}<0.05)$, and significantly higher RDW (16.0 \pm 3.1 vs. $12.7 \pm 0.6 \%, p<0.05)$, serum ferritin $[334.0 \mathrm{ng} / \mathrm{ml}(174.0-462.9)$ vs. $87.0 \mathrm{ng} / \mathrm{ml}(21.9-$ 113.1), $\mathrm{p}<0.05$ ], s-TfR $(27.1 \pm 7.6$ vs. $22.7 \pm 9.8 \mathrm{nmol} / \mathrm{l}$, $\mathrm{p}<0.05)$, CRP [5.7 mg/dl (2.4-16.5) vs. $1.5 \mathrm{mg} / \mathrm{dl}(0.8-$ $4.9), \mathrm{p}<0.05]$, IL-6 [8.1 pg/ml (4.8-13.7) vs. $1.9 \mathrm{pg} / \mathrm{ml}$ $(0-3.8), \mathrm{p}<0.05]$, prohepcidin [113.4 ng/ml (82.5-168.2) vs. $89.5 \mathrm{ng} / \mathrm{ml}(78.4-102.1), \mathrm{p}<0.05]$ and hepcidin levels [8.8 nmol/l (3.8-14.1) vs. $2.3 \mathrm{nmol} / \mathrm{l}(0-3.25), \mathrm{p}<0.05]$. No statistically significant differences were found on transferrin saturation between controls and HD patients. Among $\mathrm{HD}$ patients, non-responders had lower $\mathrm{Hb}(10.5$ \pm 1.9 vs. $11.6 \pm 1.3 \mathrm{~g} / \mathrm{dl}, \mathrm{p}<0.05)$, haematocrit (32.7 \pm 5.7 vs. $35.4 \pm 3.9 \%, \mathrm{p}<0.05)$, and higher RDW (17.5 \pm 3.7 vs. $14.5 \pm 1.0 \%$, p < 0.05$)$, s-TfR $(33.5 \pm 22.4$ vs. 23.8 $\pm 8.4 \mathrm{nmol} / \mathrm{l})$ and CRP levels [5.9 mg/dl (2.8-32.9) vs. 3.2 $\mathrm{mg} / \mathrm{dl}(1.7-13.5), \mathrm{p}<0.05]$. No statistically significant differences regarding transferrin saturation were found between responder and non-responder patients. Prohepcidin serum levels among non-responders were significantly lower than among responders $[122.5 \mathrm{ng} / \mathrm{ml}(87.9-$ 161.0) vs. $141.2 \mathrm{ng} / \mathrm{ml}(75.2-186.7)]$, but were higher than those in the control group. The same trend was found for hepcidin serum levels (fig. 1).

A statistically significant correlation was found between hepcidin serum levels and some haematological data $[R B C$ count $(r=-0.318, p=0.025)$, mean cell volume $(\mathrm{r}=0.484, \mathrm{p}<0.001)$, mean cell $\mathrm{Hb}(\mathrm{r}=0.467, \mathrm{p}=0.001)$ and RDW ( $\mathrm{r}=0.366, \mathrm{p}=0.01)$ ], iron status markers [ferritin $(\mathrm{r}=0.754, \mathrm{p}<0.0001)$ and transferrin $(\mathrm{r}=-0.508$, $\mathrm{p}<0.0001)]$ and inflammatory markers [CRP $(\mathrm{r}=0.359$, $\mathrm{p}=0.027)$ and interleukin $6(\mathrm{r}=0.547, \mathrm{p}=0.001)]$. We also found a positive correlation between prohepcidin and hepcidin serum levels $(\mathrm{r}=0.624, \mathrm{p}<0.0001)$. Multiple regression analysis showed that $\mathrm{CRP}$ as an independent 
variable was significantly associated with hepcidin serum levels $(\beta=0.62 ; p=0.06)$.

We found that HD patients had higher serum levels of prohepcidin and hepcidin as well as higher levels of markers of chronic inflammation such as ferritin, CRP and IL-6, and markers of reduced iron mobilization such as lower levels of transferrin. These results suggest that the high levels of hepcidin found in HD patients could be related to an underlying chronic inflammation. Moreover, correlations between hepcidin and inflammatory markers (CRP and IL-6) and multiple regression analysis corroborate this finding.

Among HD patients, we found that the non-responders to rhEPO therapy presented with more severe anae$\mathrm{mia}$, as shown by the significantly lower levels of $\mathrm{Hb}$ compared to responders. However, no statistically significant differences were found in serum iron status markers between the groups of patients, except for the s-TfR, which was higher among non-responders. The levels of this soluble receptor could be increased in two clinical settings: increased erythropoietic activity or iron deficiency [9]. As previously described [5], in our patients, s-TfR was an indicator of the erythropoietic effect of administrated rhEPO and not an indicator of iron body status. Moreover, no differences were found between responder and non-responder HD patients concerning iron status markers, which excludes a decrease in iron availability as the principal cause of the elevated s-TfR found in non-responder HD patients. As previously described [5], CRP is higher in HD patients who are non-responders to rhEPO therapy, indicating that inflammation is related to resistance to this therapy, which suggests that CRP is a good predictor of resistance to rhEPO therapy in $\mathrm{HD}$ patients.

Excessive hepcidin production occurs in patients with inflammatory and infectious diseases, resulting in anaemia of inflammation. As non-responder patients present high inflammatory markers, prohepcidin and hepcidin serum levels might be expected to be increased in nonresponder patients. However, we found that non-responder patients present lower prohepcidin and a trend for lower hepcidin serum levels. Recently it has been demonstrated that erythropoietin downregulates liver hepcidin expression, acting, therefore, as a hepcidin inhibitory hormone [1]. Since non-responders were treated with much higher doses of rhEPO compared with responders, the lower prohepcidin and hepcidin levels among nonresponders could be explained by this mechanism. On a broader note, despite the treatment with rhEPO, HD patients showed higher levels of prohepcidin and hepcidin.

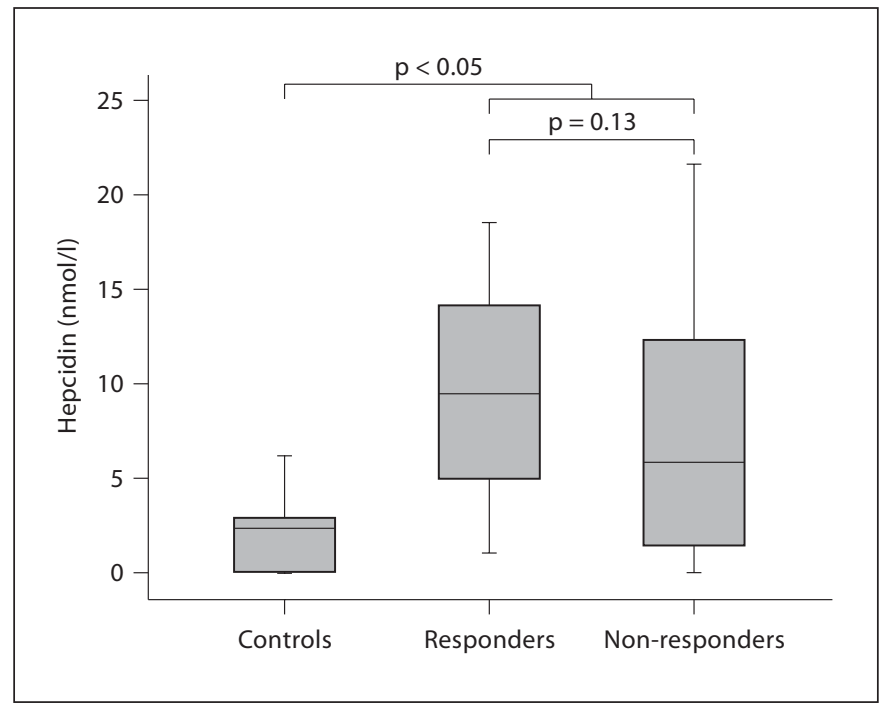

Fig. 1. Serum hepcidin levels among controls and HD patients according to the response to rhEPO therapy. Box plot shows median value (horizontal line in box) and first and third quartiles (lines above and below the box, respectively).

This could be explained by the fact that the stimulus of inflammation for prohepcidin synthesis in HD patients is stronger than the inhibitory effect of rhEPO. In addition, the use of large amounts of rhEPO may lead to increased iron utilization by the bone marrow, resulting in depletion of iron stores and ultimately decreased intracellular iron availability, which could also decrease prohepcidin and hepcidin levels. Additional explanations for the lower prohepcidin and hepcidin levels in rhEPO nonresponder patients could be lower intracellular iron availability (as reflected by the increased s-TfR observed in the non-responder group) and anaemia found in HD patients, as reflected by the negative correlation between $\mathrm{RBC}$ count and hepcidin serum levels.

In conclusion, our data show that the high hepcidin serum levels, found in HD patients, are dependent on the magnitude of the inflammatory process and on rhEPO doses. A close interaction between haematological data, inflammation, iron status and hepcidin serum levels, which ultimately regulate intracellular iron availability, was also found in our HD patients. Hepcidin seems to play a significant role in anaemia of HD patients; however, it is difficult to use it as a clinical marker due to the many influences and interrelations. 


\section{References}

1 Nicolas G, Viatte L, Bennoun M, Beaumont C, Kahn A, Vaulont S: Hepcidin, a new iron regulatory peptide. Blood Cells Mol Dis 2002;29:327-353.

-2 Kulaksiz H, Gehrke SG, Janetzko A, Rost D, Bruckner T, Kallinowski B, Stremmel W: Pro-hepcidin: expression and cell specific localisation in the liver and its regulation in hereditary haemochromatosis, chronic renal insufficiency, and renal anemia. Gut 2004; 53:735-743.

$\checkmark 3$ Dallalio G, Fleury T, Means RT: serum hepcidin in clinical specimens. Br J Haematol 2003; 122:996-1000.

$\checkmark 4$ Hsu SP, Ching CK, Chien CT, Hung KY: Plasma prohepcidin positively correlates with haematocrit in chronic hemodialysis patients. Blood Purif 2006;24:311-316.
Costa E, Pereira BJG, Rocha-Pereira P, Rocha S, Reis F, Castro E, Teixeira F, Miranda V, Sameiro Faria M, Loureiro A, Quintanilha A, Belo L, Santos-Silva A: Role of prohepcidin, inflammatory markers and iron status in resistance to rhEPO therapy in hemodialysis patients. Am J Nephrol 2008;28:677683.

6 Eleftheriadis T, Liakopoulos V, Antoniadi G, Kartsios C, Stefanidis I: The role of hepcidin in iron homeostasis and anemia in hemodialysis patients. Semin Dialysis 2009;22:7077.
7 Swinkels DW, Girelli D, Laarakkers C, Kroot J, Campostrini N, Kemna EH, Tjalsma H: Advances in quantitative hepcidin measurements by time-of-flight mass spectrometry. PLoS One 2008;3:e2706.

8 Kroot JJ, Hendriks JC, Laarakkers CM, Klaver SM, Kemna EH, Tjalsma H, Swinkels DW: (Pre)analytical imprecision, betweensubject variability, and daily variations in serum and urine hepcidin: implications for clinical studies. Anal Biochem 2009;389: 124-129.

-9 Furaso M, Munaretto G, Spinello M, Rebeschini M, Amici G, Gallieni M, Picoli A: Soluble transferrin receptors and reticulocyte hemoglobin concentration in the assessment of iron deficiency in hemodialysis patients. J Nephrol 2005;18:72-79. 